\title{
Therapists Take Note
}

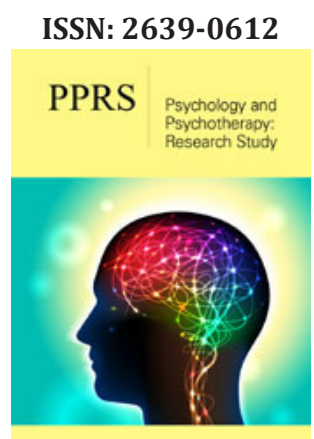

*Corresponding author: Susanna A Hayes, Cultural Psychology, USA

Submission: 眥 January 22, 2019

Published: 温January 24, 2020

Volume 3 - Issue 3

How to cite this article: Susanna A Hayes. Therapists Take Note. Psychol Psychother Res Stud. 3(3).PPRS.000561.2020.

DOI: 10.31031/PPRS.2020.03.000561

Copyright@ Susanna A Hayes, This article is distributed under the terms of the Creative Commons Attribution 4.0 International License, which permits unrestricted use and redistribution provided that the original author and source are credited.

\author{
Susanna A Hayes* \\ Cultural Psychology, USA
}

\section{Opinion}

Four recent, popular (millions sold), and highly praised books authored by women, have children as protagonists. A shared theme is the children's desperate need for parental presence, nurturing, and love. Caring adults who encounter the children recognize their desperation and respond with benevolent assistance. In Educated, a Memoir, (Westover, 2018) and The Goldfinch (Tartt, 2013) encounters with therapists were of negligible benefit. Encounters with professional helpers leave the protagonists feeling discouraged by reactions or recommendations offered in a prescribed manner or by nothing more than time spent in the presence of the therapist. The children resort to seeking help from family friends, teachers, or tapping into their personal insight and intuition.

In Where the Crawdads Sing (Owens, 2018), Kya, a little girl hopes her mother will return home to comfort and protect her from a raging, alcoholic father. She is greatly saddened when her hopes are not fulfilled. With resilience and trust, she turned to caring adults and a male peer in her community for material and empathic social and emotional support. Similarly, in The Secret Lives of Bees (Kidd, 2001), a young Lily longs for her deceased mother's companionships and comfort when her violently angry father rages against her for no apparent reason other than her existence. What are the messages these acclaimed texts communicate about the efficacy of therapists in the contemporary world? The protagonists Kya, Lily, Tara and Theo receive far greater support and compassion from merchants, teachers, older siblings, and trustworthy community members, then they receive from professional helpers.

Each character can be regarded as representative of millions of children in contemporary society who have no reliable parent or caregiver in her/his life. Rather, with natural intelligence and intuition as mainstays, they turn to adults who recognize their desperation and provide sensitive and caring, and sustained assistance. Can counselors in schools and mental health centers help children who are self-reliant by necessity years before they have reached the level of maturity when self-reliance is socially, emotionally, and economically expected? Having educated mental health and school counselors for years and served as a counselor in public schools for over 10 years, I propose they need a revised training program. Children in large and small communities are invited to join real and digital communities, many of which are not nurturing but offer a token of recognition as compensation for unfulfilled physical needs, benevolent caring, and familial belonging and support. Counselors in offices may have a full schedule of therapy sessions each day. However, after clients spend an hour with a therapist, weekly or bi-weekly, where do they go if home is a tent city, an abandoned building, a shelter sponsored by a social or church affiliated agency? Does an hour of active listening, unconditional positive regard, or rational-behavioral dialogue satisfy the anxiety, danger, or social marginalization they face on the street, in school classrooms, lunchrooms, or hallways? There are no immediate or quick fixes to the desperation children face in contemporary society. However, those who care enough to dedicate their time and talents to helping them overcome multiple challenges, are asked to evaluate the efficacy of their professional outreach in light of the vivid examples presented in the four examples encountered in the above texts..

For possible submissions Click below:

Submit Article 